Bangladesh J. Bot. 49(2): 237-248, 2020 (June)

\title{
TREE FINE ROOTS PRODUCTIVITY AND TURNOVER RATES ESTIMATION IN ALPINE SANDY LAND
}

\author{
Lili Feng ${ }^{*}$, Zhiqing Jia ANd ZhaOJIANG Zhang \\ School of Mining and Geomatics Engineering, Hebei University of Engineering, Hebei \\ Handan, 056038, China
}

Keywords: Fine roots, Turnover rates, Minimum water requirement, Alpine sandy land

\begin{abstract}
Sequential coring method was used to collect the data of fine roots from June to August in alpine sandy land. Turnover rates were calculated by maximum or mean biomass during the growing season in 2015 using Decision Matrix (DM) or Maximum-Minimum (MM) method. Results show that biomass in June is lower than that in July and August. Turnover rates of Artemisia desertorum are higher than that of Caragana intermedia and Caragana korshinskii. Turnover rates of mixed forest are higher than that of pure forest. Soil gravimetric water content is highly related to root biomass/ length in the depth of $40-60 \mathrm{~cm}$ for Caragana intermedia and Caragana korshinskii. But soil gravimetric water content and root biomass/ length have no obvious regularity in the depth of $40 \sim 60 \mathrm{~cm}$ for Artemisia desertorum. The minimum water requirement threshold of around 0.02 can be acquired for Caragana intermedia and Caragana korshinskii in the arid region. In alpine sandy land, it is suitable to plant Artemisia desertorum compared to Caragana intermedia and Caragana korshinskii; mixed forest has more advantages compared to pure forest.
\end{abstract}

\section{Introduction}

Root is the main organ of a plant to exert the mechanical effects by holding the soil and reducing the soil water content. It helps to reinforce the soil, increase slope stability and decrease water erosion (Zhang et al. 2014). Further, fine roots play an important role in the cycling of water, nutrients, and carbon in terrestrial ecosystems (McCormack et al. 2015). Tree fine roots and their turnover rates have a fundamental role in determining the response of carbon input to the soil via fine roots litter (Leppälammi-Kujansuu et al. 2014). Trees can adjust the biomass of the fine roots or foraging strategy to meet the altered environmental conditions or vary the allocation between the above ground and below ground parts of the tree (Keyes et al. 1981, Mäkelä et al. 2008, Finér et al. 2011, Ostonen et al. 2011, Leppälammi-Kujansuu et al. 2014). Of these, fine roots turnover rates are one of the most common parameters included in terrestrial process models and often used to tune below ground carbon fluxes. In addition to its influence on carbon fluxes between soil pools and atmosphere, fine roots turnover rates also affect the total amount of roots standing biomass, thus potentially influencing nutrient and water uptake by plants (McCormack et al. 2015). However, due to lack of empirical data, many belowground processes are poorly represented in ecological models (Ostle et al. 2009, Iversen 2014, Smithwick et al. 2014, McCormack et al. 2015). Soils are the major terrestrial reservoir of organic carbon, and a large part of the carbon flux into the soil takes place via fine roots and mycorrhizal turnover (Vogt et al. 1986, Helmisaari et al. 2002, Lal 2005, Godbold et al. 2006). The response of carbon flux into the forest soil is particularly interesting in relation to climate change, but the environmental and biological factors

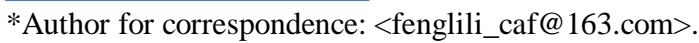


that control the fine roots mortality rate and belowground litter production are still poorly known (Leppälammi-Kujansuu et al. 2014). Connections between roots longevity and environmental factors still need further clarification (Leppälammi-Kujansuu et al. 2014). The extent to which tree roots accelerate nutrient cycling is largely unknown (Grayston et al. 1997, Högberg et al. 2006, Frank et al. 2009, Lambers et al. 2009, Yin et al. 2014). Although fine roots productivity and turnover rates are critical for cycling of water, nutrients, and carbon in terrestrial ecosystems, a few studies have directly been carried out on this subject.

The study area of Gonghe Basin is located in the north-east of Qinghai-Tibet Plateau between Qilian and Kunlun mountains. In this region, water as a primary factor for limiting physiological and ecological adaptability of plants is the most important part of artificial vegetation rehabilitation in alpine sandy land. However, there are a few studies on the threshold of trees in alpine sandy land. At present, a lot of studies focus on the aboveground. There is very little research on belowground. Fine roots turnover constitutes a major carbon input to soils. For the fine roots, Böhm (1979) defined the diameter of fine roots is between $0.5 \mathrm{~mm}$ and $2 \mathrm{~mm}$. Fogel (1983) defined the diameter of fine roots is between $2 \mathrm{~mm}$ and $5 \mathrm{~mm}$. However, it is generally defined as roots diameter is less than $2 \mathrm{~mm}$ in the current study (Pregitzer 2002). Fine roots turnover rates have been studied using several direct methods such as the sequential soil coring method, ingrowth core method and minirhizotron method, and indirect methods such as the carbon budget method, nitrogen budget method and carbon isotope method (Gill et al. 2000, Majdi et al. 2005, Satomura et al. 2007). Sequential soil coring method was widely used in the fine roots studies. The most serious drawbacks of the ingrowth cores method are (1) the ability to physically and chemically reconstruct roots in free soil environment and (2) roots production differs in a rootfree zone from that already occupied by roots (Friend et al. 1990, Steele et al. 1997, Vogt et al. 1998). For the minirhizotron method, it should be carefully considered the installation phase to minimize changing roots growth patterns. Roots growth status remains stable after one year due to the damage of installation phase. So, it needs a longer observation period (Hendrick et al. 1993, Burke et al. 1994, Rytter et al. 1996, Vogt et al. 1998). In this study, sequential soil coring method was used to obtain the fine roots turnover rates. Focus was given on two questions, (1) what is the difference of tree fine roots productivity and turnover rates between different species? (2) what is the relationship between soil gravimetric water content and fine roots biomass? The overall goal was to select a suitable shelter forest types in alpine sandy land.

\section{Materials and Methods}

Experimental data acquired from Gonghe Desert Ecosystem Research Station in Qinghai Province which is located in Gonghe Basin with large sandy area (E 99 $45^{\prime}-100^{\circ} 30^{\prime} \mathrm{N} 36^{\circ} 03^{\prime}$ $\left.36^{\circ} 40^{\prime}\right)$. This region belongs to plateau continental climate with characteristics of low and large temperature difference between day and night, less concentrated rainfall and strong solar radiation. It is a more sensitive area of climate change and fragile zone of ecology environment with average annual temperature of $2.4^{\circ} \mathrm{C}$, rainfall of $246.3 \mathrm{~mm}$ and evaporation of $1716.7 \mathrm{~mm}$. Location of study area is shown in Fig. 1.

Samples were collected in four $20 \mathrm{~m} \times 20 \mathrm{~m}$ plots in the growing season (June to August) of 2015. The main species in the study area are Caragana intermedia, Caragana korshinskii, Artemisia desertorum, mixed forest of Caragana intermedia + Artemisia desertorum on mobile dune. At the site, the tree is even-aged (2000s) with sandy soils. It was used to obtain the roots productivity and turnover rates estimation in alpine sandy land. Three trees as repetitions were carried out for per species. They were chosen as representative of their stands in terms of height and stem diameter. Data of two sampling points $(20$ and $30 \mathrm{~cm}$ from the tree) for Caragana 
intermedia, Caragana korshinskii and one sampling point $(10 \mathrm{~cm}$ from the tree) for Artemisia desertorum on each direction were collected from each depth $(0-20 \mathrm{~cm}, 20-40 \mathrm{~cm}, 40-60 \mathrm{~cm}$; 0 $-20 \mathrm{~cm}, 20-40 \mathrm{~cm}$ ). Roots were obtained by roots auger with a sampling tube $8 \mathrm{~cm}$ in diameter. Roots samples were immediately placed into sealed polyethylene bags and soil samples were kept in capped aluminum boxes for transportation. In the laboratory, roots were cleaned and distinguished into live and dead roots from each sample. Meanwhile, the soil was air-dried. The biomass of each fine roots sample was obtained after oven-drying at $80^{\circ} \mathrm{C}$ to constant weight.
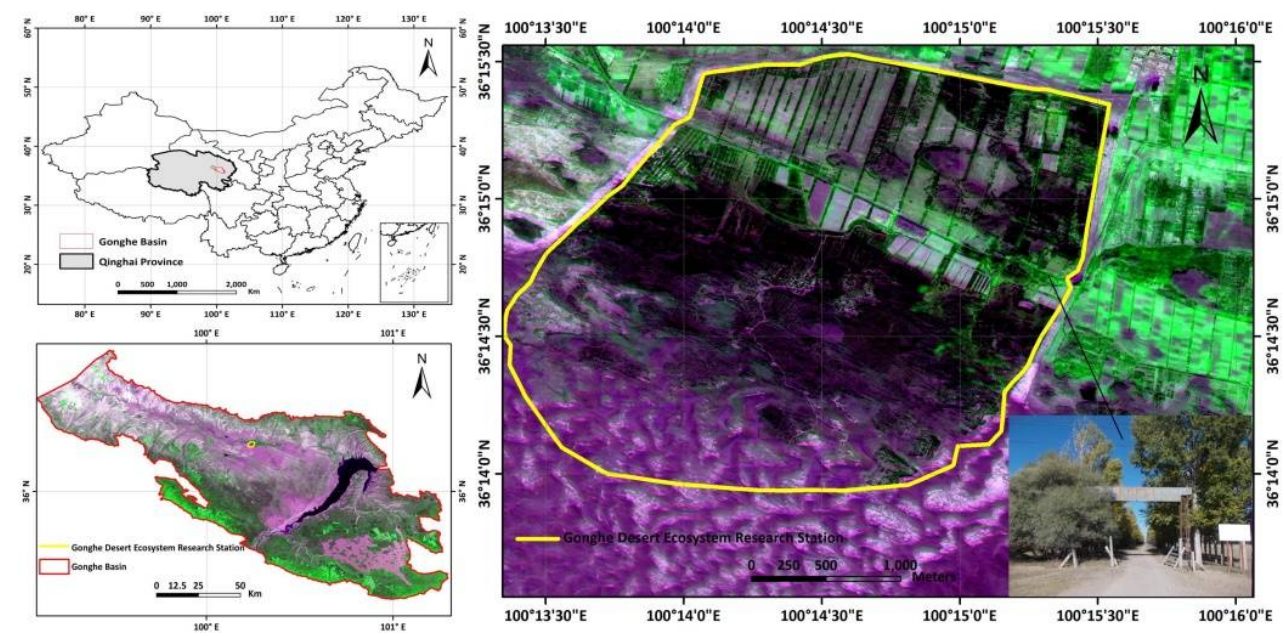

Fig. 1. Location of study area.

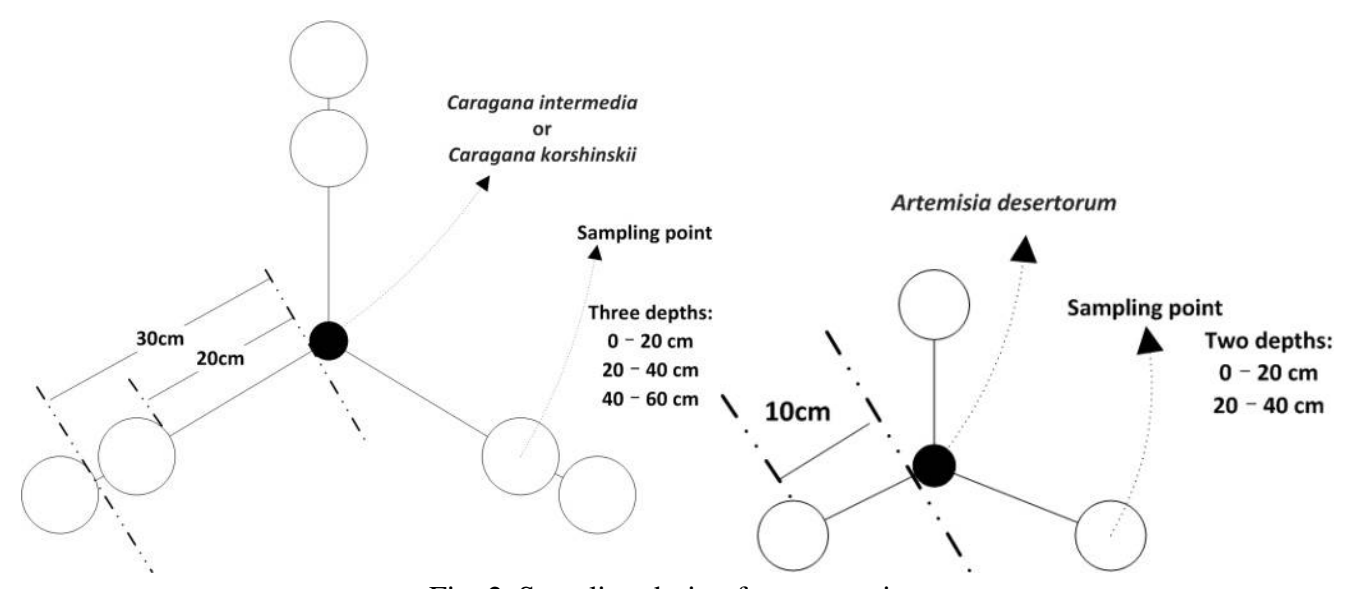

Fig. 2. Sampling design for per species.

Measurement of soil gravimetric water content was conducted using an oven-drying method $\left(105^{\circ} \mathrm{C}, 24 \mathrm{hrs}\right)$. To reduce the heterogeneity of different directions, roots and soil samples were obtained from three directions per month. Roots and soil samples were obtained from another three directions next month to reduce the heterogeneity of different trees. Sampling design for per species is shown in Fig. 2. 
Fine roots productivity and turnover rates were estimated by using the weight of roots data obtained from sequential soil coring method. Estimation of fine roots productivity can be conducted with relatively high accuracy using a large number of samples using the sequential soil coring technique (Finér et al. 2011, Brunner et al. 2013, Sun et al. 2015). In this study, sequential soil coring techniques to measure fine roots dynamic with a total of 594 sequential soil cores from different soil depths during the growing season were applied.

In this study, roots biomass is calculated by formula (1):

$$
\mathrm{B}=\mathrm{B}_{\mathrm{m}} \times 10^{4} /\left[\pi(\mathrm{d} / 2)^{2}\right]
$$

where, $B$ is the roots biomass $\left(\mathrm{g} / \mathrm{m}^{2}\right) . \mathrm{B}_{\mathrm{m}}$ is the fine roots dry weight of each sample $(\mathrm{g})$ and $\mathrm{d}=8$ is the diameter of sampling tube $(\mathrm{cm})$.

Different calculation methods lead to significantly varying estimates of fine roots turnover rates. Consequently, one must pay attention to the calculation method when comparing data reported previously. Maximum-minimum (MM) method to calculate below ground net primary productivity (BNPP) is shown in formula (2).

$$
\mathrm{BNPP}_{(\mathrm{MM})}=\mathrm{B}_{\text {max }}-\mathrm{B}_{\text {min }}
$$

where, $\mathrm{B}_{\max }$ and $\mathrm{B}_{\min }$ were the maximum and minimum biomass, respectively during the growing season.

Decision matrix (DM) method to calculate below ground net primary productivity (BNPP) is shown in formula (3):

$$
\mathrm{BNPP}_{(\mathrm{DM})}=\sum \mathrm{P}
$$

where, $\mathrm{P}$ is calculated by the differences in biomass $(\Delta \mathrm{L})$ and necromass $(\Delta \mathrm{D})$. The specific method is shown in Table 1.

Turnover rates $\mathrm{T}\left(\mathrm{yr}^{-1}\right)$ are calculated by formula (4). Soil gravimetric water content is calculated by formula (5).

$$
\mathrm{T}\left(\mathrm{yr}^{-1}\right)=\frac{\mathrm{BNPP}\left(\mathrm{g} \bullet \mathrm{m}^{-2} \bullet \mathrm{yr}^{-1}\right)}{\mathrm{B}\left(\mathrm{g} \bullet \mathrm{m}^{-2}\right)}
$$

where, $\mathrm{B}\left(\mathrm{g} \bullet \mathrm{m}^{-2}\right)$ represents maximum biomass or mean during the growing season of Qinghai province in 2015.

$$
\text { Soil gravimetric water content }=\frac{\text { Weight of wet soil }(\mathrm{g})-\text { weight of dry soil }(\mathrm{g})}{\text { Weight of dry soil }(\mathrm{g})}
$$

In the present study, a statistical Grubbs' test with confidence level of 0.95 was used to detect outliers of fine roots biomass for different species. Normally, there are 18 samples of fine roots for each depth and species, such as Caragana intermedia, Caragana korshinskii, Caragana intermedia (mixed) and 9 samples for each depth and species, such as Artemisia desertorum and Artemisia desertorum (mixed). The outliers will not be considered these data if the fine roots biomass values are abnormal through Grubbs' test. 


\section{Results and Discussion}

Mean dry matter of live and dead fine roots for Caragana intermedia, Caragana korshinskii, Artemisia desertorum, Caragana intermedia (mixed) and Artemisia desertorum (mixed) in different seasons are shown in Tables 2 to 6. Growing seasons start late in Qinghai province with low temperature and high altitude. So, at the beginning of growing seasons, the biomass in June is lower than that in July and August (Fig. 3). Turnover rates calculated by maximum or mean biomass during the growing season in 2015 using Decision Matrix (DM) or Maximum-Minimum (MM) method are presented in Table 7. Results show that turnover rates of Artemisia desertorum are higher than that of Caragana intermedia and Caragana korshinskii. Turnover rates of mixed forest are higher than that of pure forest. Soil gravimetric water content is highly related to root biomass/ length in the depth of $40-60 \mathrm{~cm}$ for Caragana intermedia and Caragana korshinskii. But soil gravimetric water content and root biomass/length have no obvious regularity in the depth from 40 to $60 \mathrm{~cm}$ for Artemisia desertorum (Figs 4 to 8). Where $\mathrm{x}$ is soil gravimetric water content, $\mathrm{y}$ is root biomass/length for different species. The minimum water requirement threshold of around 0.02 can be acquired when $y^{\prime \prime}=0$ for Caragana intermedia and Caragana korshinskii.

Table 1. Decision matrix for estimating fine root production.

\begin{tabular}{lll}
\hline & Live increase & Live decrease \\
\hline Dead increase & $\mathrm{P}=\Delta \mathrm{L}+\Delta \mathrm{D}$ & $\mathrm{P}=\Delta \mathrm{L}+\Delta \mathrm{D}($ if $|\Delta \mathrm{L}|<|\Delta \mathrm{D}|)$ \\
& $\mathrm{P}=0($ if $|\Delta \mathrm{L}|>|\Delta \mathrm{D}|)$ \\
Dead decrease & $\mathrm{P}=\Delta \mathrm{L}$ & $\mathrm{P}=0$
\end{tabular}

$\Delta=$ changes in fine root biomass or necromass, $\mathrm{L}=$ biomass, $\mathrm{D}=$ necromass, $\mathrm{P}=$ production.

Table 2. Mean dry matter of live and dead fine roots for Caragana intermedia.

\begin{tabular}{|c|c|c|c|c|c|c|}
\hline \multirow{3}{*}{$\begin{array}{l}\text { Depth } \\
(\mathrm{cm})\end{array}$} & \multicolumn{6}{|c|}{ Caragana intermedia } \\
\hline & \multicolumn{2}{|c|}{ June } & \multicolumn{2}{|c|}{ July } & \multicolumn{2}{|c|}{ August } \\
\hline & Live & Dead & Live & Dead & Live & Dead \\
\hline & & & Dry ma & $\left(\mathrm{g} / \mathrm{m}^{2}\right)$ & & \\
\hline \multirow[t]{2}{*}{$0-20$} & 60.2899 & 3.7545 & 55.9483 & 1.6022 & 38.2077 & 0.1638 \\
\hline & $(\mathrm{n}=18)$ & $(\mathrm{n}=18)$ & $(\mathrm{n}=15)$ & $(\mathrm{n}=15)$ & $(\mathrm{n}=17)$ & $(\mathrm{n}=17)$ \\
\hline \multirow[t]{2}{*}{$20-40$} & 67.6519 & 5.7473 & 81.9759 & 3.5147 & 86.9505 & 1.3418 \\
\hline & $(\mathrm{n}=18)$ & $(\mathrm{n}=18)$ & $(\mathrm{n}=18)$ & $(\mathrm{n}=18)$ & $(\mathrm{n}=18)$ & $(\mathrm{n}=18)$ \\
\hline \multirow[t]{2}{*}{$40-60$} & 59.2532 & 10.1605 & 37.6490 & 6.7342 & 53.5612 & 1.1727 \\
\hline & $(\mathrm{n}=18)$ & $(\mathrm{n}=18)$ & $(\mathrm{n}=18)$ & $(\mathrm{n}=18)$ & $(\mathrm{n}=18)$ & $(\mathrm{n}=18)$ \\
\hline Total & 187.1950 & 19.6623 & 175.5732 & 11.8511 & 178.7194 & 2.6783 \\
\hline
\end{tabular}

(1) Relationships between soil gravimetric water content and root biomass for Caragana intermedia: $\mathrm{y}=49.3927+163.3434^{*} \exp \left(-0.5^{*}((\mathrm{x}-0.0261) / 0.0003)^{\wedge} 2\right)$. When $\mathrm{y}^{\prime \prime}=0, \mathrm{x}_{1}=$ 0.0258 and $\mathrm{x}_{2}=0.0264$.

(2) Relationships between soil gravimetric water content and root length for Caragana intermedia: $\mathrm{y}=145.5266+444.9282^{*} \exp \left(-0.5^{*}((\mathrm{x}-0.0261) / 0.0002)^{\wedge} 2\right)$. When $\mathrm{y}^{\prime \prime}=0, \mathrm{x}_{1}=$ 0.0259 and $\mathrm{x}_{2}=0.0263$. 
(3) Relationships between soil gravimetric water content and root biomass for Caragana korshinskii: $\mathrm{y}=11.7360+29.1452 * \exp \left(-0.5 *((\mathrm{x}-0.0359) / 0.0074)^{\wedge} 2\right)$. When $\mathrm{y}^{\prime \prime}=0, \mathrm{x}_{1}=0.0285$ and $\mathrm{x}_{2}=0.0433$.

(4) Relationships between soil gravimetric water content and root length for Caragana korshinskii: $\mathrm{y}=82.9677+108.4413^{*} \exp \left(-0.5^{*}((\mathrm{x}-0.0384) / 0.0021)^{\wedge} 2\right)$ When $\mathrm{y}^{\prime \prime}=0, \mathrm{x}_{1}=$ 0.0363 and $\mathrm{x}_{2}=0.0405$.

Table 3. Mean dry matter of live and dead fine roots for Caragana korshinskii.

\begin{tabular}{|c|c|c|c|c|c|c|}
\hline \multirow{3}{*}{$\begin{array}{l}\text { Depth } \\
(\mathrm{cm})\end{array}$} & \multicolumn{6}{|c|}{ Caragana korshinskii } \\
\hline & \multicolumn{2}{|c|}{ June } & \multicolumn{2}{|c|}{ July } & \multicolumn{2}{|c|}{ August } \\
\hline & Live & Dead & Live & Dead & Live & Dead \\
\hline & \multicolumn{6}{|c|}{ Dry matter $\left(\mathrm{g} \mathrm{m}^{-2}\right)$} \\
\hline \multirow[t]{2}{*}{$0-20$} & 74.7542 & 0.9671 & 89.3279 & 6.9752 & 110.6624 & 3.9557 \\
\hline & $(\mathrm{n}=18)$ & $(\mathrm{n}=18)$ & $(\mathrm{n}=18)$ & $(\mathrm{n}=18)$ & $(\mathrm{n}=18)$ & $(\mathrm{n}=18)$ \\
\hline \multirow[t]{2}{*}{$20-40$} & 103.6917 & 0.0000 & 138.9478 & 0.5581 & 108.3867 & 0.5891 \\
\hline & $(\mathrm{n}=18)$ & $(\mathrm{n}=18)$ & $(\mathrm{n}=18)$ & $(\mathrm{n}=18)$ & $(\mathrm{n}=18)$ & $(\mathrm{n}=18)$ \\
\hline \multirow[t]{2}{*}{$40-60$} & 25.2870 & 0.2350 & 30.0803 & 1.0708 & 0.0000 & 59.4621 \\
\hline & $(\mathrm{n}=16)$ & $(\mathrm{n}=16)$ & $(\mathrm{n}=17)$ & $(\mathrm{n}=17)$ & $(\mathrm{n}=18)$ & $(\mathrm{n}=18)$ \\
\hline Total & 203.7329 & 1.2021 & 258.3560 & 8.6041 & 219.0491 & 64.0069 \\
\hline
\end{tabular}

Table 4. Mean dry matter of live and dead fine roots for Artemisia desertorum.

\begin{tabular}{|c|c|c|c|c|c|c|}
\hline \multirow{3}{*}{$\begin{array}{l}\text { Depth } \\
(\mathrm{cm})\end{array}$} & \multicolumn{6}{|c|}{ Artemisia desertorum } \\
\hline & \multicolumn{2}{|c|}{ June } & \multicolumn{2}{|c|}{ July } & \multicolumn{2}{|c|}{ August } \\
\hline & Live & Dead & Live & Dead & Live & Dead \\
\hline & \multicolumn{6}{|c|}{ Dry matter $\left(\mathrm{g} / \mathrm{m}^{2}\right)$} \\
\hline $0-20$ & 24.7331 & 3.6805 & 30.5489 & 7.5731 & 34.9257 & 19.5097 \\
\hline & $(\mathrm{n}=9)$ & $(\mathrm{n}=9)$ & $(\mathrm{n}=9)$ & $(n=9)$ & $(n=9)$ & $(\mathrm{n}=9)$ \\
\hline \multirow[t]{2}{*}{$20-40$} & 5.8241 & 31.6470 & 6.5187 & 8.8221 & 9.2384 & 11.5164 \\
\hline & $(\mathrm{n}=8)$ & $(\mathrm{n}=8)$ & $(n=9)$ & $(n=9)$ & $(\mathrm{n}=8)$ & $(\mathrm{n}=8)$ \\
\hline Total & 30.5572 & 35.3275 & 37.0676 & 16.3952 & 44.1641 & 31.0261 \\
\hline
\end{tabular}

Generally, the relative order of fine roots turnover rates among species was different with grass $>$ shrub > tree (Gill and Jackson 2000). Two broader conclusions can be drawn from the present study of fine roots turnover and litter production. Firstly, turnover rates of Artemisia desertorum are higher than that of Caragana intermedia and Caragana korshinskii. Turnover rates of mixed forest are higher than that of pure forest. Secondly, soil gravimetric water content is highly related to root biomass/length in the depth from 40 to $60 \mathrm{~cm}$ for Caragana intermedia and Caragana korshinskii. But soil gravimetric water content and root biomass/length have no obvious regularity in the depth of $40-60 \mathrm{~cm}$ for Artemisia desertorum. The minimum water requirement threshold of around 0.02 can be acquired for Caragana intermedia and Caragana korshinskii. Relationships between soil gravimetric water content and root biomass/length for each species 
Table 5. Mean dry matter of live and dead fine roots for Caragana intermedia (mixed).

\begin{tabular}{|c|c|c|c|c|c|c|}
\hline \multirow{3}{*}{$\begin{array}{l}\text { Depth } \\
(\mathrm{cm})\end{array}$} & \multicolumn{6}{|c|}{ Caragana intermedia (mixed) } \\
\hline & \multicolumn{2}{|c|}{ June } & \multicolumn{2}{|c|}{ July } & \multicolumn{2}{|c|}{ August } \\
\hline & Live & Dead & Live & Dead & Live & Dead \\
\hline & & & Dry ma & $\left(\mathrm{g} \mathrm{m}^{-2}\right)$ & & \\
\hline \multirow[t]{2}{*}{$0-20$} & 54.1779 & 3.6407 & 65.4304 & 7.8583 & 53.5214 & 3.6440 \\
\hline & $(\mathrm{n}=18)$ & $(\mathrm{n}=18)$ & $(\mathrm{n}=18)$ & $(\mathrm{n}=18)$ & $(\mathrm{n}=18)$ & $(\mathrm{n}=18)$ \\
\hline \multirow[t]{2}{*}{$20-40$} & 65.0247 & 6.3574 & 73.9374 & 10.8236 & 72.9394 & 1.7076 \\
\hline & $(\mathrm{n}=18)$ & $(\mathrm{n}=18)$ & $(\mathrm{n}=18)$ & $(\mathrm{n}=18)$ & $(\mathrm{n}=18)$ & $(\mathrm{n}=18)$ \\
\hline \multirow[t]{2}{*}{$40-60$} & 18.3139 & 2.4846 & 27.1067 & 6.0257 & 55.0886 & 3.5832 \\
\hline & $(\mathrm{n}=18)$ & $(\mathrm{n}=18)$ & $(\mathrm{n}=17)$ & $(\mathrm{n}=17)$ & $(\mathrm{n}=18)$ & $(\mathrm{n}=18)$ \\
\hline Total & 137.5165 & 12.4827 & 166.4745 & 24.7076 & 181.5494 & 8.9348 \\
\hline
\end{tabular}

Table 6. Mean dry matter of live and dead fine roots for Artemisia desertorum (mixed).

\begin{tabular}{|c|c|c|c|c|c|c|}
\hline \multirow{3}{*}{ Depth $(\mathrm{cm})$} & \multicolumn{6}{|c|}{ Artemisia desertorum (mixed) } \\
\hline & \multicolumn{2}{|c|}{ June } & \multicolumn{2}{|c|}{ July } & \multicolumn{2}{|c|}{ August } \\
\hline & Live & Dead & Live & Dead & Live & Dead \\
\hline & \multicolumn{6}{|c|}{ Dry matter $\left(\mathrm{g} / \mathrm{m}^{2}\right)$} \\
\hline \multirow[t]{2}{*}{$0-20$} & 21.9855 & 4.6708 & 26.1810 & 12.4713 & 20.2105 & 4.2861 \\
\hline & $(n=9)$ & $(\mathrm{n}=9)$ & $(\mathrm{n}=8)$ & $(\mathrm{n}=8)$ & $(n=9)$ & $(n=9)$ \\
\hline \multirow[t]{2}{*}{$20-40$} & 20.4713 & 5.9153 & 7.7560 & 37.1030 & 37.7971 & 5.8290 \\
\hline & $(\mathrm{n}=9)$ & $(\mathrm{n}=9)$ & $(n=7)$ & $(n=7)$ & $(n=9)$ & $(\mathrm{n}=9)$ \\
\hline Total & 42.4568 & 10.5861 & 33.9370 & 49.5743 & 58.0076 & 10.1151 \\
\hline
\end{tabular}

Table 7. Fine roots turnover rates are calculated by maximum or mean biomass during the growing season in 2015 using Decision Matrix (DM) or Maximum-Minimum (MM) method.

\begin{tabular}{|c|c|c|c|c|c|c|c|}
\hline \multicolumn{2}{|c|}{ Biomass (B) } & \multicolumn{3}{|c|}{ Decision Matrix } & \multicolumn{3}{|c|}{ Maximun-Minimum } \\
\hline \multirow{2}{*}{$\begin{array}{l}\text { Mean } \\
\left(\mathrm{g} / \mathrm{m}^{2}\right)\end{array}$} & \multirow{2}{*}{$\begin{array}{l}\text { Maximum } \\
\left(\mathrm{g} / \mathrm{m}^{2}\right)\end{array}$} & \multirow{2}{*}{$\begin{array}{l}\text { Production } \\
\left(\mathrm{g} / \mathrm{m}^{2} / \mathrm{yr}\right)\end{array}$} & \multicolumn{2}{|c|}{ Turnover rates } & \multirow{2}{*}{$\begin{array}{c}\text { Production } \\
\left(\mathrm{g} / \mathrm{m}^{2} / \mathrm{yr}\right)\end{array}$} & \multicolumn{2}{|c|}{ Turnover rates } \\
\hline & & & $\begin{array}{l}\mathrm{B}_{\text {mean }} \\
(/ \mathrm{yr})\end{array}$ & $\begin{array}{l}\mathrm{B}_{\max } \\
(/ \mathrm{yr})\end{array}$ & & $\begin{array}{c}\mathrm{B}_{\text {mean }} \\
(/ \mathrm{yr})\end{array}$ & $\begin{array}{l}\mathrm{B}_{\max } \\
(/ \mathrm{yr})\end{array}$ \\
\hline \multicolumn{8}{|c|}{ Caragana intermedia } \\
\hline 180.4959 & 187.1950 & 3.1462 & 0.0174 & 0.0168 & 11.6218 & 0.0644 & 0.0621 \\
\hline \multicolumn{8}{|c|}{ Caragana korshinskii } \\
\hline 227.0460 & 258.3560 & 156.7348 & 0.6903 & 0.6067 & 54.6231 & 0.2406 & 0.2114 \\
\hline \multicolumn{8}{|c|}{ Artemisia desertorum } \\
\hline 37.2630 & 44.1641 & 28.2378 & 0.7578 & 0.6394 & 13.6069 & 0.3652 & 0.3081 \\
\hline \multicolumn{8}{|c|}{ Caragana intermedia (mixed) } \\
\hline 161.8468 & 181.5494 & 56.2578 & 0.3476 & 0.3099 & 44.0329 & 0.2721 & 0.2425 \\
\hline \multicolumn{8}{|c|}{ Artemisia desertorum (mixed) } \\
\hline 44.8005 & 58.0076 & 71.5786 & 1.5977 & 1.2340 & 24.0706 & 0.5373 & 0.4150 \\
\hline
\end{tabular}




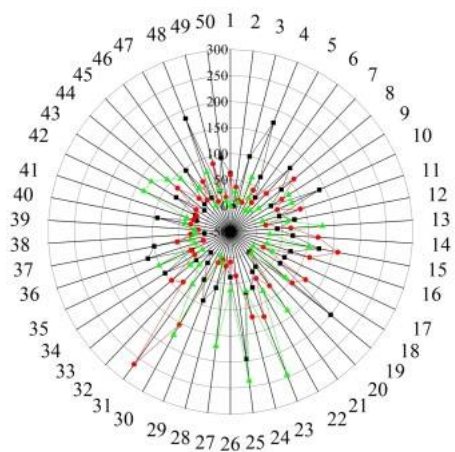

Caragana intermedia

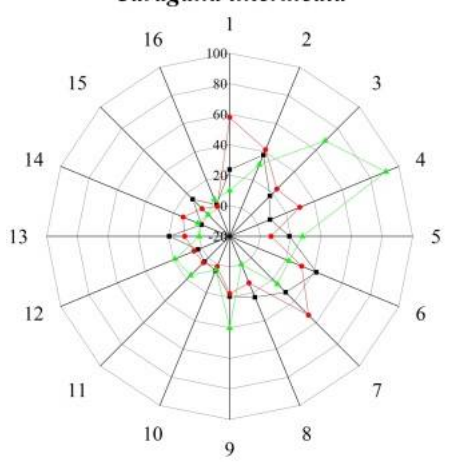

Artemisia desertorum

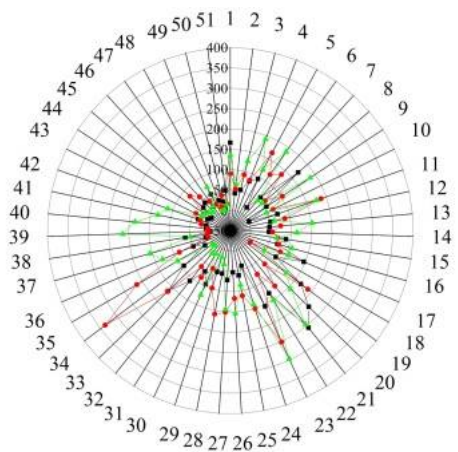

Caragana korshinskii

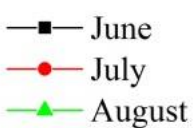

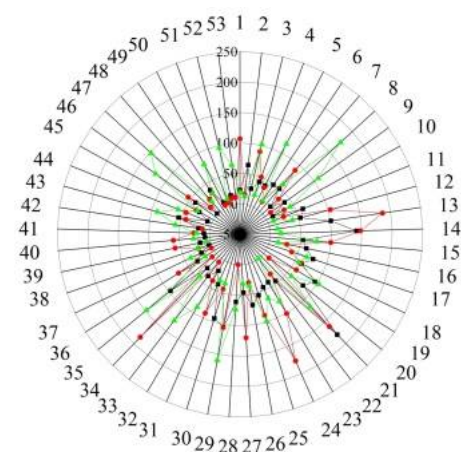

Caragana intermedia (mixed)

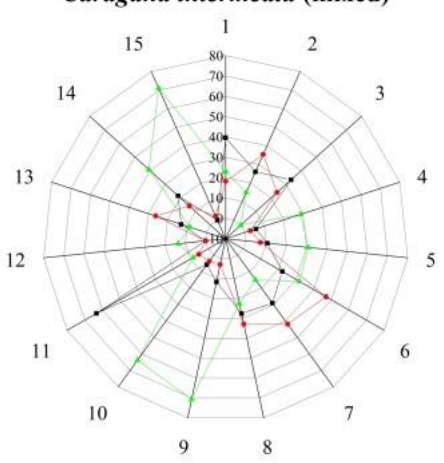

Artemisia desertorum (mixed)

Fig. 3. Dry matter of live fine roots in different seasons (This radar chart consists of a sequence of equiangular spokes, called radii, with each spoke representing one of the variables; the variable is fine roots biomass $\left(\mathrm{g} / \mathrm{m}^{2}\right)$ in this study. The data length of a spoke is the value of each variable.
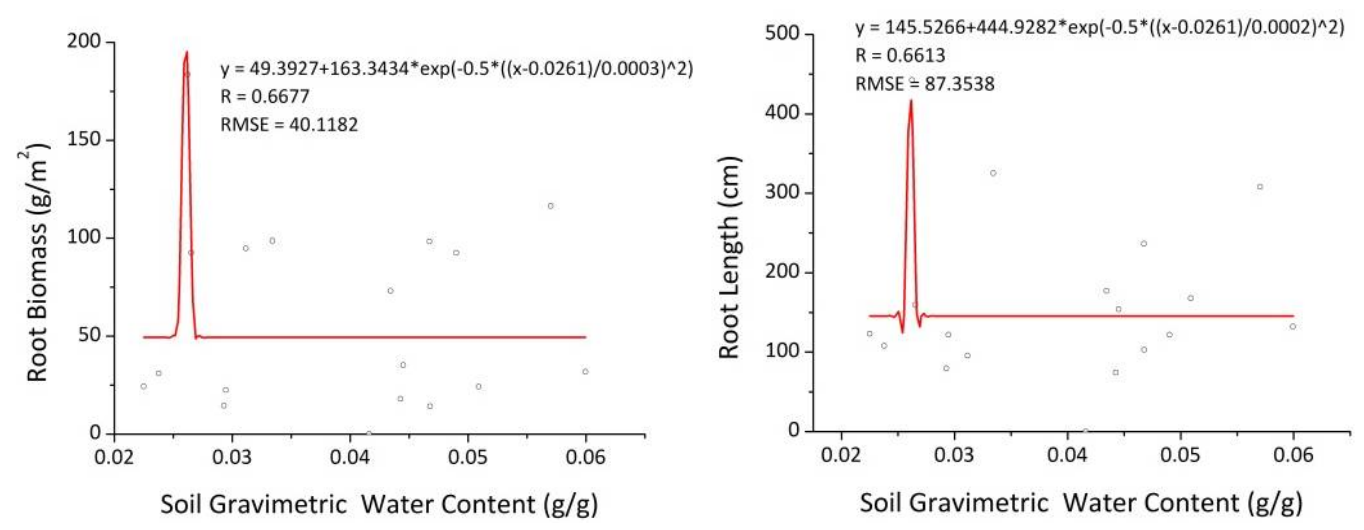

Fig. 4. Relationships between soil gravimetric water content and root biomass/length for Caragana intermedia in June, 2015. 

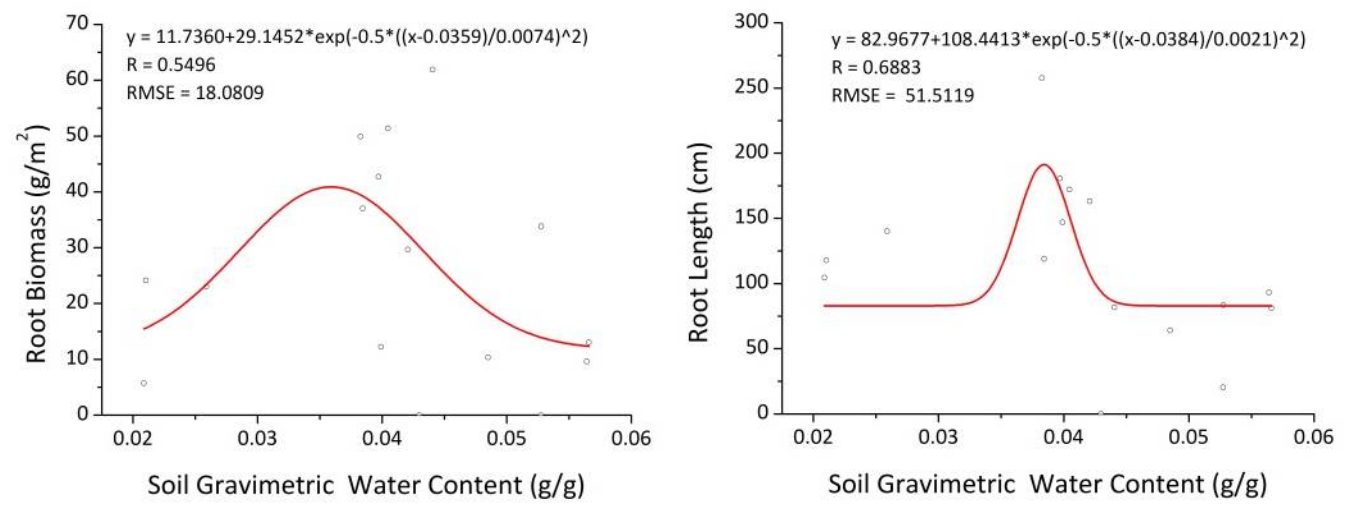

Fig. 5. Relationships between soil gravimetric water content and root biomass/ length for Caragana korshinskii in June, 2015.
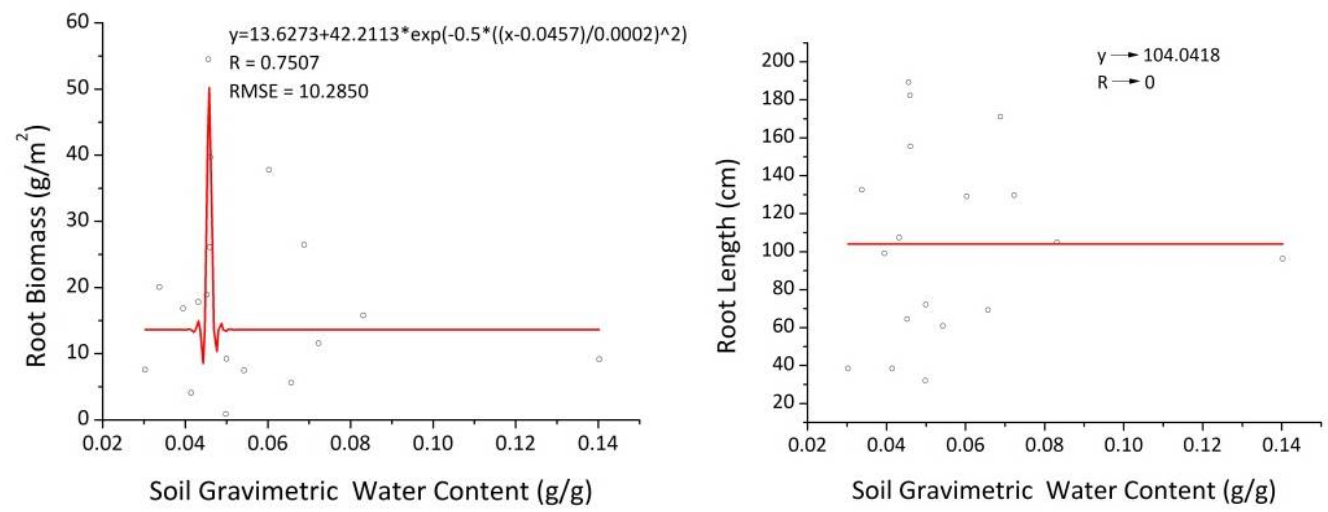

Fig. 6. Relationships between soil gravimetric water content and root biomass/length for Caragana intermedia (mixed) in June, 2015.
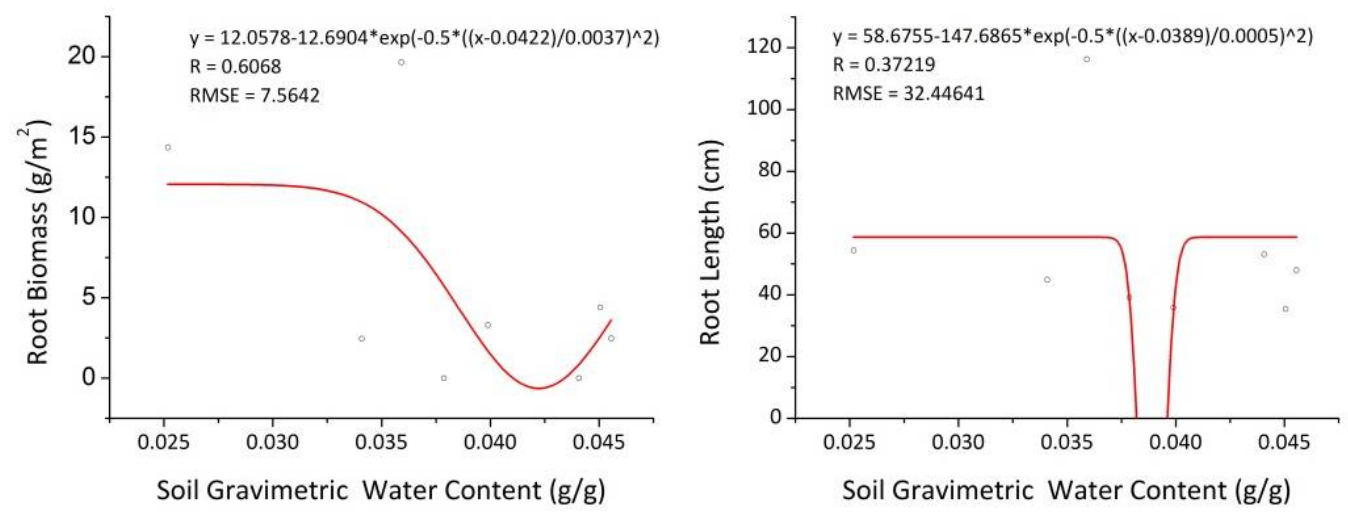

Fig. 7. Relationships between soil gravimetric water content and root biomass/length for Artemisia desertorum in June, 2015. 

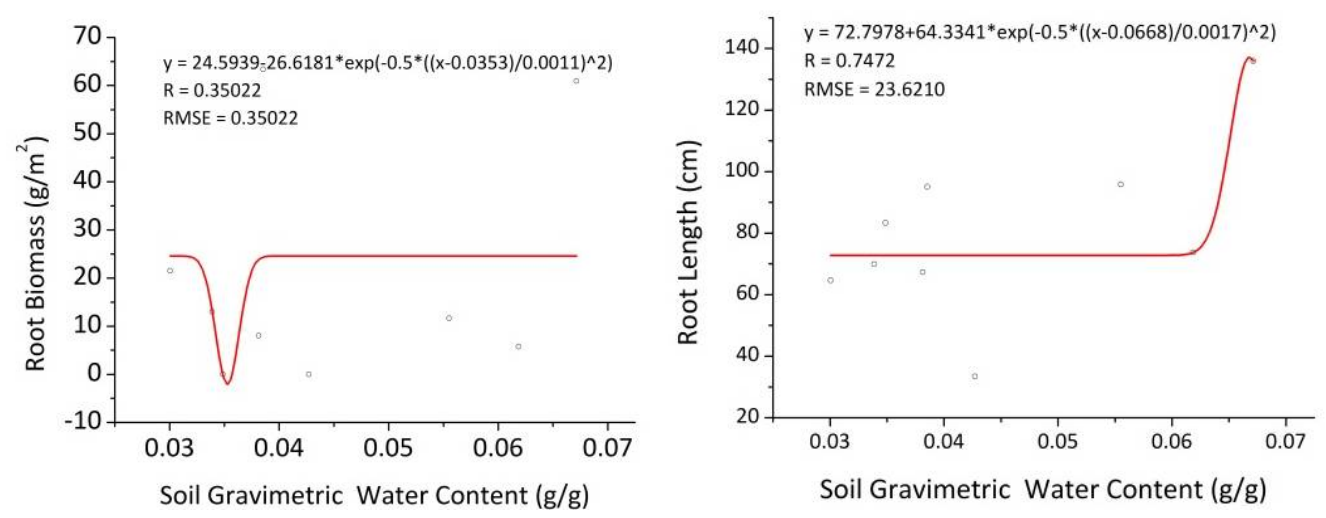

Fig. 8. Relationships between soil gravimetric water content and root biomass/ length for Artemisia desertorum (mixed) in June, 2015.

If the correlation coefficient is not high, it will not deduce the minimum water requirement threshold. Because of the effect of Artemisia desertorum, the minimum water requirement threshold for mixed forest of Caragana intermedia will not deduce by fitting formula. Root systems fulfill important functions in nutrient uptake and carbon exchange in terrestrial ecosystems. Faster fine roots turnover rates accelerated carbon cycle processes. In fact, Artemisia desertorum belongs to the type of subshrub. It is reasonable to conclude that the fine roots turnover rates of Artemisia desertorum are higher than that of Caragana intermedia and Caragana korshinskii based on previous studies. The minimum water requirement threshold of Artemisia desertorum was not obtained from the experiment. It indicates that Artemisia desertorum can bear severe water condition. Actually, these points were verified during the process of desertification control. So, in alpine sandy land, it is suitable to plant Artemisia desertorum compared to Caragana intermedia and Caragana korshinskii. Meanwhile, mixed forest has more advantages compared to pure forest.

\section{Acknowledgements}

This work was funded by Foundation of Hebei Educational Committee (QN2018054, BJ2018043), Humanities and Social Sciences Fund of Ministry of Education (18YJCZH257),

\section{References}

Brunner I, Bakker MR, Björk RG, Hirano Y, Lukac M, Aranda X, Børja I, Eldhuset TD, Helmisaari HS, Jourdan C, Konôpka B, López BC, Miguel Pérez C, Persson H and Ostonen I 2013. Fine-root turnover rates of European forests revisited: an analysis of data from sequential coring and ingrowth cores. Plant and Soil 362(1-2): 357-372.

Böhm W 1979. Methods of Studying Root Systems. Springer-Verlag.

Burke MK and raynal DJ 1994. Fine root growth phenology, production , and turnover in a northern hardwood forest ecosystems. Plant and Soil 162: 135-146.

Finér L, Ohashi M, Noguchi K and Hirano Y 2011. Fine root production and turnover in forest ecosystems in relation to stand and environmental characteristics. Forest Ecology and Management 262(11): 20082023.

Frank DA and Groffman PM 2009. Plant rhizospheric N processes: what we don't know and why we should care. Ecology 90(6): 1512-1519. 
Fogel R 1983. Root turnover and productivity of coniferous forests. Plant and Soil 71: 75- 85.

Friend AL, Eide MR and Hinckley TM 1990. Nitrogen stress alters root proliferation in Douglas-fir seedling. Canadian J. Forest Res. 20: 1524-1529.

Godbold D L, Hoosbeek MR, Lukac M, Cotrufo MF, Janssens IA, Ceulemans R, Polle A, Velthorst EJ, Scarascia-Mugnozza G, Angelis PD, Miglietta F and Peressotti A 2006. Mycorrhizal hyphal turnover as a dominant process for carbon input into soil organic matter. Plant and Soil 281(1-2): 15-24.

Grayston SJ, Vaughan D and Jones D 1997. Rhizosphere carbon flow in trees, in comparison with annual plants: the importance of root exudation and its impact on microbial activity and nutrient availability. Applied soil ecology 5(1): 29-56.

Gill RA and Jackson RB 2000. Global patterns of root turnover for terrestrial ecosystems. New Phytologist 147(1): 13-31.

Helmisaari HS, Makkonen K, Kellomäki S, Valtonen E and Mälkönen E 2002. Below-and above-ground biomass, production and nitrogen use in Scots pine stands in eastern Finland. Forest Ecology and Management 165(1): 317-326.

Högberg P and Read DJ 2006. Towards a more plant physiological perspective on soil ecology. Trends in Ecology \& Evolution 21(10): 548-554.

Hendrick RL and Pregitzer KS 1993. The dynamics of fine root, length, biomass, and nitrogen content in two northern hardwood ecosystems. Canadian Journal of Forest Research 23: 2507-2520.

Iversen CM 2014. Using root form to improve our understanding of root function. New Phytologist 203(3): 707-709.

Keyes MR. and Grier CC 1981. Above-and below-ground net production in 40-year-old Douglas-fir stands on low and high productivity sites. Canadian J. Forest Research 11(3): 599-605.

Leppälammi-Kujansuu J, Salemaa M, Kleja DB, Linder S and Helmisaari HS 2014. Fine root turnover and litter production of Norway spruce in a long-term temperature and nutrient manipulation experiment. Plant and Soil 374(1-2): 73-88.

Lal R 2005. Forest soils and carbon sequestration. Forest ecology and Management 220(1): 242-258.

Lambers H, Mougel C, Jaillard B and Hinsinger P 2009. Plant-microbe-soil interactions in the rhizosphere: An evolutionary perspective. Plant and Soil 321(1-2): 83-115.

McCormack ML, Crisfield E, Raczka B, Schnekenburger F, Eissenstat DM and Smithwick EA 2015. Sensitivity of four ecological models to adjustments in fine root turnover rate. Ecological Modelling 297: 107-117.

Mäkelä A, Valentine HT and Helmisaari HS 2008. Optimal co-allocation of carbon and nitrogen in a forest stand at steady state. New Phytologist 180(1): 114-123.

Majdi H, Pregitzer K, Moren AS, Nylund JE and Ågren GI 2005. Measuring fine root turnover in forest ecosystems. Plant and Soil 276(1-2): 1-8.

Ostonen I, Helmisaari HS, Borken W, Tedersoo L, Kukumägi M, Bahram M, Lindroos A, Nöjd P, Uri V, Merilä P, Asi E and Lõhmus K 2011. Fine root foraging strategies in Norway spruce forests across a European climate gradient. Global Change Biology 17(12): 3620-3632.

Ostle NJ, Smith P, Fisher R, Ian Woodward F, Fisher JB, Smith JU, Galbraith D, Levy P, Meir P, McNamara NP and Bardgett RD 2009. Integrating plant-soil interactions into global carbon cycle models. J. Ecology 97(5): 851-863.

Pregitzer KS 2002. Fine roots of trees - A new perspective. New Phytologist 154(2): 267-270.

Rytter RM and Hansson AC 1996. Seasonal amount, growth and depth distribution of fine roots in an irrigated and fertilized, Salix viminalis L. plantation. Biomass and Bioenergy 11(2- 3): 129.

Smithwick EA, Lucash MS, McCormack ML and Sivandran G 2014. Improving the representation of roots in terrestrial models. Ecological Modelling 291: 193-204.

Satomura T, Fukuzawa K and Horikoshi T 2007. Considerations in the study of tree fine-root turnover with minirhizotrons. Plant Root 1: 34-45.

Sun T, Dong L, Mao Z and Li Y 2015. Fine root dynamics of trees and understorey vegetation in a chronosequence of Betula platyphylla stands. Forest Ecology and Management 346: 1-9. 
Steele SJ, Gower ST, Vogel JG and Norman JM 1997. Root mass, net primary production and turnover in aspen, jack pine and black spruce forests in Saskatchewan and Manitoba, Canada. Tree Physiology 17(8-9): 577-587.

Vogt KA, Grier CC and Vogt DJ 1986. Production, turnover, and nutrient dynamics of above- and belowground detritus of world forests. Advances in Ecological Research 15(3): 3-377.

Vogt KA, Vogt DJ and Bloomfield J 1998. Analysis of some direct and indirect methods fox estimating root biomass and production of forests at an ecosystem level. Plant and Soil 200: 71- 89.

Yin H, Wheeler E and Phillips RP 2014. Root-induced changes in nutrient cycling in forests depend on exudation rates. Soil Biology and Biochemistry 78: 213-221.

Zhang CB, Chen LH and Jiang J 2014. Why fine tree roots are stronger than thicker roots: The role of cellulose and lignin in relation to slope stability. Geomorphology 206: 196-202.

(Manuscript received on 6 May, 2018; revised on 2 July, 2019) 